\title{
Melatonin, immune function and aging
} V Srinivasan1, GJM Maestroni², DP Cardinali3 ${ }^{3}$, AI Esquifino4, SR Pandi Perumal ${ }^{5}$ and SC Miller*6

\begin{abstract}
Address: ${ }^{1}$ Department of Physiology, School of Medical Sciences, University Sains Malaysia 16150, Kubang Kerian, Kelantan, Malaysia, ${ }^{2}$ Center for Experimental Pathology, Cantonal Institute of Pathology, Via In Selva 24, PO Box 660, Locarno, Switzerland, ${ }^{3}$ Departamento de Fisiología, Facultad de Medicina, Universidad de Buenos Aires, 1121 Buenos Aires, Argentina, ${ }^{4}$ Departamento de Bioquímica y Biología Molecular, Facultad de Medicina, Universidad Complutense, 28040, Madrid, Spain, ${ }^{5}$ Section of Sleep Medicine, Division of Clinical Neurophysiology and Epilepsy, Department of Neurology, College of Medicine, SUNY Downstate Medical Center, Brooklyn NY, 11203-2098, USA and ${ }^{6}$ Department of Anatomy and Cell Biology, Strathcona Anatomy \& Dentistry Building, McGill University, Montreal, PQ, H3A 2B2, Canada
\end{abstract}

Email: V Srinivasan - saisrinivasaya@yahoo.com; GJM Maestroni - georges.maestroni@ti.ch; DP Cardinali - danielcardinali@fibertel.com.ar; AI Esquifino - pelayos@med.ucm.es; SR Pandi Perumal - pandiperumal@gmail.com; SC Miller* - sandra.miller@mcgill.ca

* Corresponding author

Published: 29 November 2005

Immunity \& Ageing 2005, 2:17 doi:10.1186/1742-4933-2-17

This article is available from: http://www.immunityageing.com/content/2/1/17

2005 Srinivasan et al, licensee BioMed Central Ltd.

This is an Open Access article distributed under the terms of the Creative Commons Attribution License (http://creativecommons.org/licenses/by/2.0), which permits unrestricted use, distribution, and reproduction in any medium, provided the original work is properly cited.

\begin{abstract}
Aging is associated with a decline in immune function (immunosenescence), a situation known to correlate with increased incidence of cancer, infectious and degenerative diseases. Innate, cellular and humoral immunity all exhibit increased deterioration with age. A decrease in functional competence of individual natural killer (NK) cells is found with advancing age. Macrophages and granulocytes show functional decline in aging as evidenced by their diminished phagocytic activity and impairment of superoxide generation. There is also marked shift in cytokine profile as age advances, e.g., CD3+ and CD4+ cells decline in number whereas CD8+ cells increase in elderly individuals. A decline in organ specific antibodies occurs causing reduced humoral responsiveness. Circulating melatonin decreases with age and in recent years much interest has been focused on its immunomodulatory effect. Melatonin stimulates the production of progenitor cells for granulocytes-macrophages. It also stimulates the production of NK cells and CD4+ cells and inhibits CD8+ cells. The production and release of various cytokines from NK cells and T-helper lymphocytes also are enhanced by melatonin. Melatonin presumably regulates immune function by acting on the immune-opioid network, by affecting G protein-cAMP signal pathway and by regulating intracellular glutathione levels. Melatonin has the potential therapeutic value to enhance immune function in aged individuals and in patients in an immunocompromised state.
\end{abstract}

\section{Introduction}

Aging is a complex physiological process that involves a number of biochemical reactions, with molecular changes that are manifested in single cells as well as in the whole organism. Aging reflects the sum total of all changes that occur in living organisms with the passage of time that lead to functional impairment and increased pathology. Aging is characterized by a diminished ability to respond to stress [1]. Among the many theories proposed for aging, the Oxidative Theory of Aging put forth by Harman in 1956 [2] has received wide support.

Aging is associated with a decline in immune function known as immunosenescence. This situation implies increased susceptibility to infectious diseases and cancer due to a decreased capacity of the immune system to 
respond to antigenic stimulation [3]. This results in altered cytokine microenvironment and impairment of both innate and adaptive immunity [4]. It is interesting to note that many hormones that are associated with maintenance of immune function also decline with advancing age and the interrelationship between the endocrine system and the immune system is considered of crucial importance in normal human physiology and in mediating age-associated degenerative diseases [5-8]. The decline in the production of a number of hormones associated with aging such as growth hormone (GH), estrogen and dehydroepiandrosterone, as well as of the pineal substance melatonin, have been proposed to play a significant role in contributing to immunosenesecence [5]. Among these, melatonin has been demonstrated to bear a general immunoenhancing effect in many animal species as well as in humans [9].

Melatonin is a natural antioxidant with significant antiaging properties [10]. Indeed, any search for a therapeutic agent that can improve the quality of life in the elderly implies the identification of substances that have both antioxidant and immunoenhancing qualities. In this vein, the role for melatonin has been put forth [11-13] and in this paper the evidence indicating that melatonin is effective to combat age associated decline in immune function will be reviewed with the aim of advocating melatonin as a possible therapeutic agent for enhancing the quality of life in the elderly.

\section{Aging and immune function}

Immunosenescence is associated with increased incidence of cancer and of degenerative and infectious diseases. The progressive functional $\mathrm{T}$ cell and $\mathrm{B}$ cell deficits may be the main responsible factors for age-associated disorders $[4,14,15]$. The involution of thymus with age results in alterations of gene expression [16]; indeed, immunosenescence is reflected at cellular, molecular and genetic levels [17]. Individuals of the same chronological age may exhibit variations in the degree of senescence associated functional impairment [18]. The role of immunity as a predictor of individual longevity in human beings has been suggested by several studies like OCTO and NONA longitudinal studies and they all reveal the existence of "immunological risk phenotype", that can predict the life span in the elderly [19].

\section{Aging and innate immunity}

Aging affects the innate immune system [20]. In the innate immune system natural killer (NK) cells play an important role for inhibiting cancer and metastases. Longer life in centenarians has been associated with increased NK cell number, augmented interferon (IFN)gamma production and phagocytosis [21-23]. The ageassociated increases in NK cells (21) have been inter- preted as a compensatory response to overcome the generally decreased immune function and has been considered helpful in arresting the growth of neoplastic cells. For example, in human NK cells from healthy subjects over 90 years of age, the ability to synthesize chemotactic cytokines upon stimulation by IL-12 or IL-2, or to express the corresponding chemokine receptors are maintained (24). However most investigators are of the opinion that functional competence of individual human NK cells declines with age $[21,25]$. Indeed, NK cells of aged people exhibited a diminished production of IFN gamma and chemokines in response to interleukin (IL)-2 and IL6 [25]. Recently, Albright and her coworkers [26] found severe impairment in the production of mRNA transcripts representing several cytokines in NK/LAK cells of aged mouse. The cytotoxic capacity of NK cell is well preserved in peripheral blood of the centenarians [27].

Functional impairment of macrophages and granulocytes are reported in the elderly. Diminished intracellular phagocytic activity, degranulation and decrease in chemotactic and phagocytic activity have all been found in polymorphonuclear leukocytes of elderly individuals $[24,28]$. In a study in centenarians, Miyaji and his coworkers [22] found that granulocytes exhibited decreased superoxide production, irrespective of subject's health conditions. A decrease in superoxide production in elderly subjects has also been reported in other studies [29-31], the decreased production of superoxide in the granulocytes being attributed to the reduction in signal transduction in granulocytes [29]. The attenuation of Fc mediated superoxide generation and phagocytosis in the elderly has been suggested as the major factor for the age-related decline in neutrophil function $[28,32]$. With regard to macrophages, increased production of proinflammatory mediators like IL-1, IL-6 and IL-8 occurs in both healthy aged subjects and people showing pathological aging $[33,34]$. Macrophages are important for phagocytosis and destruction of microorganisms and also for cytokine production that regulates the functional ability of other cells of innate immunity.

Diminished IL-1 levels and diminished generation of reactive oxygen species (ROS) from monocytes of elderly subjects has been reported (reviewed by [35]). IL-6 (which has been termed as a "cytokine for gerontologists", [36]) increases in aged subjects $[37,38]$. The increase in IL-6 occurs in healthy individuals older than 85 years of age [39]. The increase in IL-6 seen in aged subjects may contribute to age-ssociated diseases [40] and mortality [41]. Plasma concentrations of soluble intercellular adhesion molecule-1 (ICAM-1) increased with age [39,42,43]. Collectively, the results suggest that it is this shift in cytokine profile that is largely responsible for triggering immu- 
nosenescence and increased morbidity and mortality in the elderly [39].

\section{Aging and humoral immunity}

Aging results in changes in humoral immunity such as an increase in the levels of serum immunoglobulins like IgA and $\mathrm{IgG}$, and decrease in the number of $\mathrm{B}$ and $\mathrm{T}$ lymphocytes $[44,45]$. A decline in organ specific autoantibodies together with an increase in non-organ specific autoantibodies have been found in the elderly [46]. Reduction in CD 27+ memory B cells has been reported and this correlated with low $\mathrm{T}$ cell number [47]. A decrease in CD5+ B cells independent of T cell decline was also reported in aging [48]. Therefore, the reduced humoral responsiveness and altered antibody-mediated defense mechanisms seen in aged individuals are explained mainly by an intrinsic primary cell deficit [49]. The ability of $\mathrm{T}$ cells to promote B-cell activation and antibody production may be compromised in elderly individuals, as suggested by studies using cytometric phenotypic analysis [50]. A significant decrease in IL-2 production with aging plays a role in reducing antibody production $[23,49]$.

\section{Aging and cellular immunity}

Aging not only causes changes in innate immunity and humoral immunity, but also causes changes in cellular immunity. A significant decrease in $\mathrm{CD} 3+, \mathrm{CD} 4+, \mathrm{CD} 8+$ cells and naïve $\mathrm{T}$ lymphocytes (CD45RA+CD4+) occurs with increase in age. An extensive review on T cell function in aging was published by Pawelec et al. [14]. With aging, alterations in signal transduction may also occur. The ageassociated decline in $\mathrm{T}$ cell function is preceded by involution of the thymus [35]. The striking feature of T cell alterations in aging is the marked shift from naive to memory cells with an imbalance of virgin and memory cells being noted especially in CD8+ T lymphocytes [45]. Naïve T cells, which are concerned with the mounting primary immune response, are dependent upon CD28, a co-stimulatory signal for their proliferation [45]. Both the decrease in the number of naïve $T$ cells and in their responsiveness with aging cause the decline of specific immunization response in aged individuals [51]. Large increases in CD8+ T cells with receptors for single epitopes of cytomegalovirus are common in the elderly [52]. Longitudinal studies (OCTO) suggest that the cluster of immune parameters like low CD4+ cells, an increase in CD8+ cells and a low IL-2 production are all predictive of mortality [53-55]. The decline in naïve T cells is one of the factors that cause a decreased IL-2 production[56].

\section{Melatonin}

Melatonin (N-acetyl-5-methoxytryptamine) is formed mainly in the pineal gland of most mammals including man [57]. In the pineal gland, serotonin is converted in to melatonin through a two-step enzymatic process involving $\mathrm{N}$ acetylation followed by O-methylation. In humans, plasma melatonin level begins to increase steadily after $1900 \mathrm{~h}$ to $2300 \mathrm{~h}$ to attain the peak values at around 0200 - $0400 \mathrm{~h}$ [7]. The study of plasma melatonin among subjects of different age groups reveals a consistent decrease as aging progresses. With some exceptions $[58,59]$ the decline of melatonin with age has been repeatedly reported [60-66]. The melatonin day/night rhythm has been found altered with phase advance in the elderly as compared to young women [67]. Great variations in the amplitude of nocturnal melatonin secretions are found among individuals suggesting that some individuals produce significantly less melatonin during lifetime than others; this may have an impact in terms of aging $[7,68]$. The loss of amplitude of melatonin rhythm in the advanced age is both an indication as well as a cause of age-related disturbances in the circadian pacemaker leading to chronobiological disorders [69]. This is accompanied by a general deterioration of cognitive, psychological and social functioning as well as by sleep disturbances [7072].

The age-related impairment of the immune system first appears around 60 years of age coinciding with the decrease of plasma melatonin concentration. Indeed, melatonin has a defined immunomodulatory role both in animals and humans $[13,73]$. The diurnal and seasonal changes in the immune system have been shown to correlate with melatonin synthesis and secretion [74]. Melatonin is synthesized by human lymphocytes and this finding adds further support to the hypothesis that melatonin plays a role in the regulation of human the immune system [75].

\section{Melatonin receptors}

Melatonin exerts its many physiological actions by acting on membrane and nuclear receptors although many of its actions are receptor-independent (e.g., scavenging of free radicals, interaction with cytosol proteins like calmodulin). The two melatonin receptors cloned (MT1 and MT2) are membrane receptors that have seven membrane domains and belong to the superfamily of G-protein coupled receptors [76]. Melatonin receptor activation induces a variety of responses that are mediated both by pertussissensitive and insensitive G proteins [77]. In the cytosol melatonin interacts with calmodulin [78]. Nuclear binding receptors have been identified in human lymphocytes and monocytes [79].

\section{Melatonin and immune function}

In recent years much attention has been devoted to the possible interaction between melatonin and the immune system $[13,73,80]$. Melatonin has significant immunomodulatory roles in immunocompromised states. In 
1986, Maestroni et al. first showed that inhibition of melatonin synthesis causes inhibition of cellular and humoral responses in mice [81]. Mice kept under constant light, or receiving injections of betaadrenergic blockers (propranolol) to inhibit melatonin synthesis, exhibited an inability to mount a primary antibody response to sheep red blood cells (SRBC), a decreased cellularity in thymus and spleen and a depressed autologous mixed lymphocyte reaction; all these were reversed by melatonin administration at the late afternoon [81]. Late afternoon injection of melatonin increases both the primary and secondary antibody responses to SRBC [82]. Indeed, the immunoenhancing effect of melatonin was evident only when melatonin was administered in the afternoon or in the presence of T-dependent antigenic stimulation. Since melatonin was ineffective in vitro, Maestroni and coworkers concluded that it exerts its immunostimulating effect through other neuroendocrine mechanisms in antigen-activated cells [83]. Hamsters exposed to short photoperiods had increased spleen weight and number of splenic lymphocytes and macrophages [84]. A key finding-albeit in young adult humans - with respect to the interplay of melatonin and the immune system, was the observation that the nocturnal rise of blood melatonin in humans correlated with the increase of thymic production of peptides like thymosin-1 alpha and thymulin [85].

\section{Melatonin and innate immunity}

A number of studies support the immunoregulatory action of melatonin on the body's innate immunity [80]. Melatonin stimulates the production of progenitor cells for granulocytes and macrophages (GM-CFU) and has a general stimulatory action on hemopoiesis [86,87]. Melatonin receptors are detectable in monocyte/macrophage lineage [79] and melatonin binding to these receptors stimulates the production of GMCFU cells [88,89]. A recent pivotal study, although carried out in young adult mice, has revealed a profound, time-dependent influence of melatonin on certain cells fundamentally important to the immune system. Exogenous melatonin augments NK cells and monocytes in both the bone marrow and the spleen with a latency of 7 to 14 days [90]. As both these cells are components of the non-specific immune system, the findings suggest that melatonin could be an effective way for arresting neoplastic growth and for destroying virus infected cells. The action of melatonin on monocyte production can be partly due to its direct action on melatonin receptors or may be due to an increase of monocyte sensitivity to stimulants like IL-3, IL-4, IL-6 or GM-colony stimulating factor (GM-CSF) [88-90]. As stromal cells contain receptors for kappa opioid cytokine peptides, melatonin-induced release of opioid peptides from these stromal cells in bone marrow could be involved in the regulation of hemopoietic cell proliferation [91]. In addition to monocytes, the bone marrow precursor cells for the granulocyte lineage increase in absolute numbers after melatonin administration. The study of Currier et al. [90] revealed that melatonin increases the actual production of the GM-cell lineage and not the inter-organ trafficking of myeloid precursors. An increased activation of monocytes/macrophages by melatonin has been reported in yet another study in rodents [92]. As both macrophage cells and neutrophils form important components of the innate immune system, the stimulatory action of melatonin reflects a significant immunoenhancing property. Melatonin treatment restores the decreased total leukocyte count in peripheral blood and bone marrow of pinealectomized squirrels [93]. Macrophages have been shown to form large amounts of nitric oxide (NO) upon activation by ROS that mediate their microbiocidal properties. This excessive production of NO can be harmful to the body as it can result in the development of degenerative diseases [94]. In a recent study melatonin was found to decrease NO concentration in macrophages by suppressing inducible NO synthase expression [95]. When melatonin's effects on phagocytic activity of macrophages were tested at different concentrations, the greatest phagocytic stimulation was obtained when melatonin was added resembling the unstressed situation [96].

NK cells play an important role in immunosurveillance against neoplasia and virus infected cells [97,98]. IFNgamma enhances NK cell activity [99]. An observation of potentially high prophylactic significance, was the demonstration that exogenous melatonin given acutely at $1800 \mathrm{~h}$ to young healthy males increased their responsiveness to IFN while the chronic administration of melatonin augmented the spontaneous NK cell activity and also the circulating number of NK cells [100]. The increased NK cell number brought about by melatonin administration was attributed partly to the increased production of cytokines by melatonin-stimulated T helper cells. IL-2, IL6, IL-12 and IFN-gamma have all been suggested as the possible cytokines that mediate melatonin-induced increase of NK cell number [90]. T helper cells contain melatonin receptors that presumably mediate melatonin action in releasing cytokines [101-103].

\section{Melatonin and cytokine production}

Melatonin has been proposed to regulate the immune system by affecting cytokine. production in immunocompetent cells [104]. Melatonin enhances the production of IL2, IFN-gamma and IL-6 by cultured human mononuclear cells [101]. Melatonin, by. activating monocytes [105], increases the production of IL-1, IL-6, TNF-alpha and ROS. Melatonin also increases IL-12 production by monocytes [105]. Repeated stimulation of T helper (Th) cells in the presence of IL-12 causes Th cells to differentiate into Th1 cells, which produce IL-2 and IFN-gamma and are particularly effective in enhancing immune 
responses that involve macrophages and other phagocytes. Melatonin augments IFN-gamma production by Th1 cells [104]. The enhancement of NK cell activity by melatonin is attributed to the increased production of IL2 and IL-12 [104,106,107].

Human lymphocytes themselves play an important role in stimulating IL-2. production in an autocrine or paracrine fashion [75]. After melatonin treatment, up-regulation of gene expression for TGF- $\beta$, M-CSF, TNF- $\alpha$, and stem cell factor (CSF) in peritoneal exudate cells, and the level of gene expression of IL- $1 \beta$, M-CSF, TNF- $\alpha$, IFN- $\gamma$, and SCF in splenocytes were reported [108]. Melatonin's immunoenhancing effect depends upon its ability to enhance the production of cytokines as well as its antiapoptotic and antioxidant action. As a functional impairment of macrophages and granulocytes (as shown by the diminished intracellular phagocytic activity, degranulation and decrease in chemotactic activity) has been reported in the elderly $[28,44]$ and a parallel decrease in melatonin production occurs [60-66] it may not be unreasonable to speculate that immunosenescence can be partly attributed to a decreased production of melatonin. To restore the defective phagocytic function the use of adjuvants with immunizations and nutritional supplements has been proposed [109].

Micronutrients like zinc, selenium and vitamin E play a vital role in phagocytic function [110]. Since melatonin can stimulate the immune response and correct immunodeficiencies by causing up-regulation of cytokine production it can be used therapeutically for correcting the immunodeficiency state associated with aging.

\section{Melatonin and cellular and humoral immunity} Besides its stimulatory action on the production of several cytokines that regulate immune function, melatonin's immunoenhancing properties have been attributed to a direct action on the immunocompetent cells (e.g. granulocyte-macrophage cells, NK cells and lymphocytes). Earlier studies demonstrated that the thymus is a primary target of melatonin's action. The thymus is an organ of youth in mammals, yet any influences on the thymus in youth will have profound effects on the immune system of elderly mammals. A milestone, earlier demonstration revealed that pinealectomized, young mice underwent accelerated involution of the thymus [111]. The presence of melatonin binding sites in membrane preparations of non-mammalian (duck) thymus has also been reported [112]. Mice kept under constant light, or administered with beta-adrenergic blockers exhibited decreased cellularity of thymus and spleen that was reversed by late afternoon administration of exogenous melatonin [81,82,113].
The severe loss of thymocytes with age is the main cause of structural thymic atrophy and thymic weight loss. Melatonin administration increased the total number of thymocytes in old mice [114]. In that study, thymic cell number in 2 months-old mice was $12.6 \times 10^{7}$, while it dropped to $7.3 \times 10^{7}$ cells in 24 months-old animals; in melatonin treated old mice the total number of thymocytes was $9.1 \times 10^{7}$ cells [114]. This protective effect of melatonin on thymocytes was attributed to its antiapoptotic action. Melatonin inhibited glucocorticoid- or hydroxyl radical-induced thymic apoptosis $[115,116]$. The reversal of age-associated thymic involution by melatonin added further support to the concept that melatonin can be a potential therapeutic agent for correcting immunodeficiency state associated with aging and possibly other immunocompromised states like severe stress [117]. Finally, Yu et al. [118] have demonstrated that orally administered melatonin can substantially promote the survival (anti-apoptosis) of precursor B lymphocytes (responsible for humoral immunity) in the B lymphocyte generating site, i.e., the bone marrow. This indicates that melatonin treatment can boost the survival of mature $\mathrm{B}$ cells which are the functional elements in humoral immunity.

\section{Melatonin and T lymphocyte function}

Melatonin enhances both cell-mediated and humoral immunity. The administration of melatonin to normal or immunocompromised mice elevated in vitro and in vivo antibody responses [73]. The immunoenhancing effect of melatonin involves opiod peptides; melatonin stimulates Th cells to secrete opiod peptides that have upregulatory effects on a variety of immune cells [73]. According to Nelson and Drazen [119], melatonin is a part of a complex physiological system that coordinates reproductive, immunological and other physiological processes to cope up with energetic stressors during winter. Studies in birds also indicate that melatonin stimulates both cellular and humoral responses and that the response involves opiate intermediates [120,121].

The immunostimulatory role of melatonin is exerted mainly on Th cells and on T lymphocyte precursors. There is a possibility that melatonin could act as an autocoid in bone marrow as shown by the demonstration of melatonin synthesis in bone marrow cells of mice and humans [122]. The existence of specific melatonin binding sites inlymphoid cells provides evidence for a direct effect of melatonin in the regulation of the immune system. By using the melatonin agonist $2\left[{ }^{125} \mathrm{I}\right]$-melatonin high affinity binding sites and a signal tranduction pathway for melatonin have been characterized in human lymphocytes $[123,124]$. Melatonin also counteracted the inhibitory effect of prostaglandin E2 on IL-2 production in human lymphocytes via its MT1 membrane receptor 
[125]. Melatonin augments CD4+ lymphocytes and decreases CD8+ lymphocytes in rat submaxillary lymph nodes [126]. Collectively, these studies indicate that melatonin possesses important immunoenhancing properties and suggest that melatonin may favor a Th-1 response. During the natural history of human immunodeficiency virus type I (HIV-1) infection, an impairment of IL-12 production precedes a switch from a Th-1 to a Th- 2 stage of cellular immunity. A recent study indicated a correlation of serum levels of melatonin and IL-12 in a cohort of 77 HIV-1 infected individuals, the decreased levels of serum melatonin found in HIV-1-infected individuals being possibly instrumental in the impairment of Th-1 immune response [127].

Besides the release of proinflammatory Th-1 cytokines, such as IFN-gamma and IL2 administration of melatonin to antigen-primed mice increased the production of IL10, indicating that melatonin can also activate anti-inflammatory Th-2-like immune responses in certain circumstances [128]. Therefore, it is not yet clear whether melatonin acts only on Th- 1 cells or also affects Th- 2 cells. This is an important subject as the Th-1/Th-2 balance is significant for the immune response [73]. Relevant to this, melatonin treatment suppressed the subsequent in vitro stimulation by the mitogenic agents LPS (that stimulates B cells) and Con A (that stimulates T cells) in submaxillary lymph nodes [126]. In addition, an inhibitory influence of melatonin on parameters of the immune function has also been demonstrated, i.e., in human NK cell activity, DNA synthesis, IFN-gamma and TNF-alpha synthesis, as well as the proliferation of T lymphocytes and lymphoblastoid cell lines were depressed by melatonin [73]. Melatonin can correct immunodeficiencies secondary to acute stress, viral diseases and drug treatment. In immunodepressed conditions, the immunoenhancing action of melatonin seems to be restricted to T lymphocyes [129]. In conditions of immunodeficiency, as in other pathologies and the normal, melatonin appears to favour a Th1 lymphocyte response [108]. Finally, a recent study (130) has estabished a significant role for melatonin, i.e., as an adjuvant with vaccination in sheep afflicted with ovine footrot, indicating that this agent clearly has significant benefits in health maintenance and disease treatment.

\section{Mechanism of action of melatonin in immune responses}

Studies by Drazen and Nelson [102] indicated that melatonin receptor subtype MT2 but not MT1, is involved in melatonin-induced enhancement of cell-mediated and humoral function in mice. CAMP signal transduction plays an important role in regulating lymphocyte function and this pathway appeared to be abnormal in aged mice[131]. Melatonin antagonized partially forskolininduced increase of cAMP levels of lymphocytes; indeed,
G1 protein coupled adenylate cyclase-cAMP signal pathway may be one of the important mechanisms for the anti-inflammatory immunoregulation by melatonin [132]. Melatonin enhanced significantly met-enkephalin in 2 and 11 months old mice, and the effect was blocked by nifedipine, a Ca2+ antagonist [132]. This suggests that melatonin promotes the production of met-enkephalin through L-type Ca2+ channel. Melatonin-induced immunoregulation may depend upon immuno-opiod interaction [133].

It has been suggested that Th- 1 responses are readily transformed into Th-2 dominance through depletion of intracellular GSH [134]. GSH in its reduced form is the single most important protective and regulatory antioxidant in cells. The work of Peterson and his coworkers [135] showed that depletion of glutathione from antigen presenting cells in vivo resulted in lowered Th- 1 activity and higher Th-2 activity. Murata et al. [136,137] showed that oxidized macrophages exhibited higher levels of oxidized glutathione as they polarized to type Th- 2 cells. Thus the immune activity can have Th- 1 or Th- 2 characteristics depending upon the relative antioxidant status of the cells.

Since melatonin stimulates the production of glutathione [138] its immunoenhancing role may be partly due to its influence on the maintenance of intracellular glutathione level. Indeed, melatonin acts as a hypnotic-chronobiotic $[139,140]$ with cytoprotective properties [141,142] as well as an immunoenhancing agent. Indeed, melatonin not only acts as a hypnotic-chronobiotic with cytoprotective properties but also as an immunoenhancing agent. Melatonin provides a functional link between the neuroendocrine and immuno-hematopoietic systems [143].

Recent studies reveal that not only melatonin but also its oxidation product N1 acetyl-N2-formyl-5-methoxykynuramine (AFMK) is very effective in acting onneutrophils $[144,145]$. Both melatonin and AFMK have been shown to inhibit IL- 8 release from neutrophils and AFMK has been found to be more active than melatonin in this aspect. The production of TNF-alpha by neutrophils is also inhibited by melatonin and AFMK. Since TNF-alpha and IL-8 contribute to the severity of inflammatory conditions [146], the finding of melatonin inhibiting the release of IL-8 and TNF-alpha assumes significance for it may help to reduce acute and chronic inflammation. Neutrophils are more responsive than monocytes to AFMK suggesting that melatonin biosynthesis and metabolism participate in the chemical communication among leukocytes. Melatonin may be effective in optimizing intrinsic immune responses rather than acting simply as an antioxidant [147]. Dietary supplementation of melatonin has been shown to change mRNA levels of many genes and to 
arrest the attenuated immune responses associated with senescence [147].

\section{Melatonin and season-dependent immune function}

A number of recent studies point out that seasonal changes exert influence on immune function and melatonin may play an important role in this aspect. Seasonal changes of immune function in animals are mediated by the duration of melatonin secretion, which acts as a photoperiodic signal [119]. Such seasonal changes in immune function have been observed in humans also. Increased production of proinflammatory cytokines IFN-gamma and alpha occurred during winter [148]. Highest production of IL- 6 was reported in healthy volunteers during autumn/winter season [149]. In humans the seasonal changes in immune functions can be mediated by the changes in duration of melatonin secretion. Seasonal changes in cytokines like IL-6, IFN-alpha, IFN or the balance of Th- 1 and Th- 2 response can account for seasonal changes in mood and behavior, such as Seasonal Affective Disorder.

\section{Summary}

The age-associated decline in immune function, known as immunosenescence, is characterized by a decrease in the functional activity of NK cells, granulocytes and macrophages. There is significant reduction in IL-1 and diminished generation of ROS from monocytes. In addition, there is an increase of IL- 6 production. Besides causing changes in innate immunity, aging is associated with changes in cellular and humoral immunity. Decreases of CD3 and CD4 and increases of CD8 cells occur in elderly individuals. The decrease in IL-2 production that occurs during aging causes a reduced antibody formation. Melatonin seems to play a significant immunomodulatory role. Melatonin enhances both innate and cellular immunity. It stimulates the production of progenitor cells of granulocytes and macrophages and of NK cells. Production of IL-2, IL-6 and IL-12 is stimulated by melatonin. Increased T-helper production, particularly of CD4+ cells, occurs after melatonin supplementation. Melatonin decreases CD8+ cells. Melatonin may act through the immune-opiod network. The regulation of immune function by melatonin appears to involve cAMP signal transduction, L-type Ca2+ channels and glutathione. The seasonal changes in immune function observed in animals and humans are likely to be mediated by the changes in the duration of melatonin secretion.

\section{Acknowledgements}

The author (VS) thanks Puan Rosnida Said of the Department of Physiology, School of Medical Sciences, University Sains Malaysia, for secretarial assistance in the preparation of this manuscript.

\section{References}

I. Weinert BT, Timiras PS: Invited review: Theories of aging. J Appl Physiol 2003, 95:1706-1716.

2. Hardman D: Aging: a theory based on free radical and radiation chemistry. J Gerontol 1956, I I:298-300.

3. Pawelec G, Akbar A, Caruso C, Effros R, Grubeck-Loebenstein B, Wikby A: Is immunosenescence infectious? Trends Immunol 2004, 25:406-4I0.

4. Hakim FT, Flomerfelt FA, Boyiadzis M, Gress RE: Aging, immunity and cancer. Curr Opin Immunol 2004, 16:151-156.

5. Arlt $W$, Hewison $M$ : Hormones and immune function: implications of aging. Aging Cell 2004, 3:209-216.

6. Srinivasan V: Melatonin oxidative stress and neurodegenerative diseases. Indian J Exp Biol 2002, 40:668-679.

7. Karasek M: Melatonin, human aging, and age-related diseases. Exp Gerontol 2004, 39: 1723-1729.

8. Pawelec G, Ouyang Q, Colonna-Romano G, Candore G, Lio D, Caruso C: Is human immunosenescence clinically relevant? Looking for 'immunological risk phenotypes'. Trends Immunol 2002, 23:330-332.

9. Nelson RJ: Seasonal immune function and sickness responses. Trends Immunol 2004, 25:187-192.

10. Reiter RJ, Tan D, Osuna C, Gitto E: Actions of melatonin in the reduction of oxidative stress. A review. J Biomed Sci 2000, 7:444-458.

II. Reiter RJ, Calvo JR, Karbownik M, Qi W, Tan DX: Melatonin and its relation to the immune system and inflammation. Ann $N$ Y Acad Sci 2000, 91 7:376-386.

12. Hotchkiss AK, Nelson RJ: Melatonin and immune function: hype or hypothesis? Crit Rev Immunol 2002, 22:35I-37I.

13. Esquifino AI, Pandi-Perumal SR, Cardinali DP: Circadian organization of the immune response: A role for melatonin. Clin Appl Immunol Rev 2004, 4:423-433.

14. Pawelec G, Effros RB, Caruso C, Remarque E, Barnett Y, Solana R: T cells and aging (update february 1999). Front Biosci 1999, 4:D2 16-D269.

15. Pawelec G: Immunosenescence: impact in the young as well as the old? Mech Ageing Dev 1999, 108:1-7.

16. Fry TJ, Mackall CL: Current concepts of thymic aging. Springer Semin Immunopathol 2002, 24:7-22.

17. Tarazona R, Solana R, Ouyang Q, Pawelec G: Basic biology and clinical. impact of immunosenescence. Exp Gerontol 2002, 37:183-189.

18. Sohal RS, Allen RG: Oxidative stress as a causal factor in differentiation and aging: a unifying hypothesis. Exp Gerontol 1990, 25:499-522.

19. Pawelec G, Solana R: Immunoageing - the cause or effect of morbidity. Trends Immunol 200I, 22:348-349.

20. van den Biggelaar AH, Huizinga TW, de Craen AJ, Gussekloo J, Heijmans BT, Frolich M, Westendorp RG: Impaired innate immunity predicts frailty in old age. The Leiden 85-plus study. Exp Gerontol 2004, 39:|407-|4|4.

21. Borrego F, Alonso MC, Galiani MD, Carracedo J, Ramirez R, Ostos B, Pena J, Solana R: NK phenotypic markers and IL2 response in NK cells from elderly people. Exp Gerontol 1999, 34:253-265.

22. Miyaji C, Watanabe H, Toma H, Akisaka M, Tomiyama K, Sato Y, Abo T: Functional alteration of granulocytes, NK cells, and natural killer T cells in centenarians. Hum Immunol 2000, 6 I:908-9 I 6.

23. Bonafe M, Valensin S, Gianni W, Marigliano V, Franceschi C: The unexpected contribution of immunosenescence to the leveling off of cancer incidence and mortality in the oldest old. Crit Rev Oncol Hematol 2001, 39:227-233.

24. Mariani E, Meneghetti A, Neri S, Ravaglia G, Forti P, Cattini L, Facchini $A:$ Chemokine production by natural killer cells from nonagenarians. Eur J Immunol 2002, 32: I524-I529.

25. Ginaldi L, De Martinis M, D'Ostilio A, Marini L, Loreto MF, Quaglino $D$ : The immune system in the elderly: III. Innate immunity. Immunol Res 1999, 20:1 I7-126.

26. Albright JW, Bream JH, Bere EW, Young HA, Winkler-Pickett R, Ortaldo JR: Aging of innate immunity: functional comparisons of NK/LAK cells obtained from bulk cultures of young and aged mouse spleen cells in high concentrations of interleukin-2. Exp Gerontol 2004, 39:73-82.

27. Krishnaraj R: Senescence and cytokines modulate the NK cell expression. Mech Ageing Dev 1997, 96:89-101. 
28. Fulop T Jr, Foris G, Worum I, Paragh G, Leovey A: Age related variations of some polymorphonuclear leukocyte functions. Mech Ageing Dev 1985, 29:18.

29. Lipschitz DA, Udupa KB, Boxer LA: The role of calcium in the age-related decline of neutrophil function. Blood 1988 7I:659-665.

30. Indelicato SR, Udupa KB, Balazovich KJ, Boxer LA, Lipschitz DA Effect of age on phorbol-ester stimulation of human neutrophils. J Gerontol 1990, 45:B75-B80.

31. Lipschitz DA, Udupa KB, Indelicato SR, Das M: Effect of age on second messenger generation in neutrophils. Blood 1991, 78: $1347-1354$

32. Lord JM, Butcher S, Killampali V, Lascelles D, Salmon M: Neutrophil ageing and immunesenescence. Mech Ageing Dev 200I, I22:1521-1535.

33. Rich EA, Mincek MA, Armitage KB, Duffy EG, Owen DC, Fayen JD, Hom DL, Ellner J]: Accessory function and properties of monocytes from healthy. elderly humans for $T$ lymphocyte responses to mitogen and antigen. Gerontology 1993, 39:93-108.

34. Franceschi C, Bonafe M, Valensin S, Olivieri F, De Luca M, Ottavian $\mathrm{E}$, De Benedictis G: Inflamm-aging. An evolutionary perspective on immunosenescence. Ann N Y Acad Sci 2000, 908:244-254.

35. Castle SC: Clinical relevance of age-related immune dysfunction. Clin Infect Dis 2000, 3 1:578-585.

36. Ershler WB: Interleukin-6: a cytokine for gerontologists. J Am Geriatr Soc 1993, 41:176-181.

37. Mysliwska J, Bryl E, Foerster J, Mysliwski A: Increase of interleukin 6 and decrease of interleukin 2 production during the ageing process are influenced by the health status. Mech Ageing Dev 1998, 1 00:313-328.

38. Straub RH, Miller LE, Scholmerich J, Zietz B: Cytokines and hormones as possible links between endocrinosenescence and immunosenescence. J Neuroimmunol 2000, 109:10-15.

39. Forsey RJ, Thompson JM, Ernerudh J, Hurst TL, Strindhall J, Johansson $\mathrm{B}$, Nilsson BO, Wikby A: Plasma cytokine profiles in elderly humans. Mech Ageing Dev 2003, I 24:487-493.

40. Ferrucci L, Harris TB, Guralnik JM, Tracy RP, Corti MC, Cohen HI Penninx B, Pahor M, Wallace R, Havlik RJ: Serum IL-6 level and the development of disability in older persons. J Am Geriatr Soc 1999, 47:639-646.

4I. Harris TB, Ferrucci L, Tracy RP, Corti MC, Wacholder S, Ettinger WH Jr, Heimovitz H, Cohen HJ, Wallace R: Associations of elevated interleukin-6 and C-reactive protein levels with mortality in the elderly. Am J Med 1999, 106:506-5 I2

42. Morisaki N, Saito I, Tamura K, Tashiro J Masuda M, Kanzaki T, Watanabe S, Masuda Y, Saito Y: New indices of ischemic heart disease and aging: studies on the serum levels of soluble intercellular adhesion molecule-I (ICAM-I) and soluble vascular cell adhesion molecule-I (VCAM-I) in patients with hypercholesterolemia and ischemic heart disease. Atherosclerosis 1997, I 31:43-48.

43. Miles EA, Thies F, Wallace FA, Powell JR, Hurst TL, Newsholme EA, Calder PC: Influence of age and dietary fish oil on plasma soluble adhesion molecule concentrations. Clin Sci (Lond) 200I, 100:91-100.

44. Ginaldi L, Loreto MF, Corsi MP, Modesti M, De Martinis M: Immunosenescence and infectious diseases. Microbes Infect 200I, 3:851-857.

45. Fagnoni FF, Vescovini R, Passeri G, Bologna G, Pedrazzoni M, Lavagetto G, Casti A, Franceschi C, Passeri M, Sansoni P: Shortage of circulating naive CD8(+) $T$ cells provides new insights on immunodeficiency in aging. Blood 2000, 95:2860-2868.

46. Weksler ME, Szabo P: The effect of age on the B-cell repertoire. I Clin Immunol 2000, 20:240-249.

47. Breitbart E, Wang X, Leka LS, Dallal GE, Meydani SN, Stollar BD: Altered memory B-cell homeostasis in human aging. J Gerontol A Biol Sci Med Sci 2002, 57:B304-B3II.

48. Colonna-Romano G, Bulati M, Aquino A, Scialabba G, Candore G, Lio D, Motta M, Malaguarnera M, Caruso C: B cells in the aged: CD27, CD5, and CD40 expression. Mech Ageing Dev 2003, I 24:389-393.

49. Ginaldi L, De Martinis M, D'Ostilio A, Marini L, Loreto MF, Corsi MP, Quaglino D: The immune system in the elderly: I. Specific humoral immunity. Immunol Res 1999, 20:101-108.

50. Cossarizza A, Ortolani C, Monti D, Franceschi C: Cytometric analysis of immunosenescence. Cytometry 1997, 27:297-3I3.
5I. Linton PJ, Haynes L, Tsui L, Zhang X, Swain S: From naive to effector-alterations with aging. Immunol Rev 1997, I 60:9-18.

52. Ouyang Q, Wagner WM, Zheng W, Wikby A, Remarque EJ, Pawelec G: Dysfunctional CMV-specific CD8+ $T$ cells accumulate in the elderly. Exp Gerontol 2004, 39:607-6I3.

53. Ferguson FG, Wikby A, Maxson P, Olsson J, Johansson B: Immune parameters in a longitudinal study of a very old population of Swedish people: a comparison between survivors and nonsurvivors. J Gerontol A Biol Sci Med Sci I995, 50:B378-B382.

54. Wikby A, Maxson P, Olsson J, Johansson B, Ferguson FG: Changes in CD8 and CD4 lymphocyte subsets, $T$ cell proliferation responses and non survival in the very old: the Swedish longitudinal OCTO-immune study. Mech Ageing Dev 1998, 102: $187-198$.

55. Olsson J, Wikby A, Johansson B, Lofgren S, Nilsson BO, Ferguson FG: Age related change in peripheral blood $\mathrm{T}$-lymphocyte subpopulations and cytomegalovirus infection in the very old: the Swedish longitudinal OCTO immune study. Mech Ageing Dev 2000, I 2 | : |87-20 |

56. Ginaldi L, De Martinis M, D'Ostilio A, Marini L, Loreto MF, Quaglino $D$ : The immune system in the elderly: III. Innate immunity. Immunol Res 1999, 20: I 17-126.

57. Cardinali DP, Pévet P: Basic aspects of melatonin action. Sleep Med Rev 1998, 2:175-190.

58. Zeitzer JM, Daniels JE, Duffy JF, Klerman EB, Shanahan TL, Dijk DJ, Czeisler CA: Do plasma melatonin concentrations decline with age? Am J Med 1999, 1 07:432-436.

59. Fourtillan JB, Brisson AM, Fourtillan M, Ingrand I, Decourt JP, Girault $\mathrm{J}$ : Melatonin secretion occurs at a constant rate in both young and older men and women. Am J Physiol Endocrinol Metab 200I, 280:EI I-E22

60. Iguchi $\mathrm{H}$, Kato $\mathrm{KI}$, Ibayashi $\mathrm{H}$ : Age-dependent reduction in serum melatonin. concentrations in healthy human subjects. J Clin EndocrinolMetab 1982, 55:27-29.

6I. Dori D, Casale G, Solerte SB, Fioravanti M, Migliorati G, Cuzzoni G, Ferrari E: Chrono-neuroendocrinological aspects of physiological aging and senile dementia. Chronobiologia 1994 21:|2|-|26.

62. Girotti L, Lago M, lanovsky O, Carbajales J, Elizari MV, Brusco LI, Cardinali DP: Low urinary 6-sulphatoxymelatonin levels in patients with coronary artery disease. J Pineal Res 2000, 29: | 38- 142

63. Siegrist C, Benedetti C, Orlando A, Beltran JM, Tuchscherr L, Noseda $\mathrm{CM}$, Brusco LI, Cardinali DP: Lack of changes in serum prolactin, FSH, TSH, and estradiol after melatonin treatment in doses that improve sleep and reduce benzodiazepine consumption in sleep-disturbed, middle-aged, and elderly patients. J Pineal Res 2001, 30:34-42.

64. Mishima K, Okawa M, Hozumi S, Hishikawa Y: Supplementary administration of artificial bright light and melatonin as potent treatment for disorganized circadian rest-activity and dysfunctional autonomic and neuroendocrine systems in institutionalized demented elderly persons. Chronobiol Int 2000, 17:419-432.

65. Luboshitzky R, Shen-Orr Z, Tzischichinsky O, Maldonado M, Herer P, Lavie P: Actigraphic sleep-wake patterns and urinary 6-sulfatoxymelatonin excretion in patients with Alzheimer's disease. Chronobiol Int 2001, I 8:513-524.

66. Mishima K, Okawa M, Shimizu T, Hishikawa Y: Diminished melatonin secretion in the elderly caused by insufficient environmental illumination. J Clin Endocrinol Metab 200I, 86:I29-I34.

67. Skene DJ, Swaab DF: Melatonin rhythmicity: effect of age and Alzheimer's disease. Exp Gerontol 2003, 38:199-206.

68. Bergiannaki JD, Soldatos CR, Paparrigopoulos T], Syrengelas M, Stefanis CN: Low and high melatonin excretors among healthy individuals. J Pineal Res 1995, I 8: | 59-164.

69. Srinivasan V: Melatonin, biological rhythm disorders and phototherapy. Indian J Physiol Pharmacol 1997, 41:309-328.

70. Pandi-Perumal SR, Seils LK, Kayumov L, Ralph MR, Lowe A, Moller H, Swaab DF: Senescence, sleep, and circadian rhythms. Ageing Res Rev 2002, I:559-604

7I. Monti JM, Alvarino F, Cardinali D, Savio I, Pintos A: Polysomnographic study of the effect of melatonin on sleep in elderly patients with chronic primary insomnia. Arch Gerontol Geriatr 1999, 28:85-98. 
72. Brzezinski A, Vangel MG, Wurtman RJ, Norrie G, Zhdanova I, Ben Shushan A, Ford I: Effects of exogenous melatonin on sleep: a meta-analysis. Sleep Med Rev 2005, 9:4I-50.

73. Maestroni G]: The immunotherapeutic potential of melatonin Expert Opin Investig Drugs 2001, 10:467-476.

74. Skwarlo-Sonta K: Melatonin in immunity: comparative aspects. Neuroendocrinol Lett 2002, 23(Suppl I):6I-66.

75. Carrillo-Vico A, Calvo JR, Abreu P, Lardone PJ, Garcia-Maurino S, Reiter RJ, Guerrero JM: Evidence of melatonin synthesis by human lymphocytes and its physiological significance: possible role as intracrine, autocrine, and/or paracrine substance. FASEB / 2004, I 8:537-539.

76. Dubocovich ML, Cardinali DP, Delagrange P, Krause DN, Strosberg $D$, Sugden D, Yocca FD: Melatonin receptors. In The IUPHAR Compendium of Receptor Characterization and Classification 2nd edition. Edited by: IUPHAR. London: IUPHAR Media; 2000:27I-277.

77. McArthur AJ, Hunt AE, Gillette MU: Melatonin action and signal transduction in the rat suprachiasmatic circadian clock: activation of protein kinase $\mathbf{C}$ at dusk and dawn. Endocrinology 1997, I 38:627-634.

78. Benitez-King G, Huerto-Delgadillo L, Anton-Tay F: Melatonin modifies calmodulin cell levels in MDCK and NIE-I I 5 cell lines and inhibits phosphodiesterase activity in vitro. Brain Res 1991, 557:289-292.

79. Garcia-Maurino S, Pozo D, Calvo JR, Guerrero JM: Correlation between nuclear melatonin receptor expression and enhanced cytokine production in human lymphocytic and monocytic cell lines. J Pineal Res 2000, 29: I 29- I 37.

80. Guerrero JM, Reiter RJ: Melatonin-immune system relationships. Curr Top Med Chem 2002, 2:167-179.

81. Maestroni G], Conti A, Pierpaoli W: Role of the pineal gland in immunity. Circadian synthesis and release of melatonin modulates the antibody response and antagonizes the immunosuppressive effect of corticosterone. I Neuroimmunol 1986, 13:19-30

82. Maestroni GJ, Conti A, Pierpaoli W: Role of the pineal gland in immunity: II.Melatonin enhances the antibody response via an opiatergic mechanism. Clin Exp Immunol 1987, 68:384-39I.

83. Maestroni GJ, Conti A, Pierpaoli W: The pineal gland and the circadian, opiatergic, immunoregulatory role of melatonin. Ann N Y Acad Sci 1987, 496:67-77.

84. Peters BA, Sothmann M, Wehrenberg WB: Blood leukocyte and spleen lymphocyte immune responses in chronically physically active and sedentary hamsters. Life Sci 1989 , 45:2239-2245

85. Molinero P, Soutto M, Benot S, Hmadcha A, Guerrero JM: Melatonin is responsible for the nocturnal increase observed in serum and thymus of thymosin alphal and thymulin concentrations: observations in rats and humans. I Neuroimmunol 2000, I03:180-188.

86. Maestroni G], Conti A: Melatonin and the immune-hematopoietic system therapeutic and adverse pharmacological correlates. Neuroimmunomodulation 1996, 3:325-332.

87. Maestroni GJ: The photoperiod transducer melatonin and the immune hematopoietic system. J Photochem Photobiol B 1998 , 43:186- 192.

88. Maestroni GJ, Conti A, Lissoni P: Colony-stimulating activity and hematopoietic rescue from cancer chemotherapy compounds are induced by melatonin via endogenous interleukin 4. Cancer Res 1994, 54:4740-4743.

89. Maestroni G], Covacci V, Conti A: Hematopoietic rescue via Tcell dependent, endogenous granulocyte-macrophage colony-stimulating factor induced by the pineal neurohormone melatonin in tumor-bearing mice. Cancer Res 1994 54:2429-2432

90. Currier NL, Sun LZ, Miller SC: Exogenous melatonin: quantitative enhancement in vivo of cells mediating non-specific immunity. J Neuroimmunol 2000, 104:101-108.

91. Maestroni G]: Is hematopoiesis under the influence of neural and neuroendocrine mechanisms? Histol Histopathol 1998 , | 3:27|-274.

92. Kaur C, Ling EA: Effects of melatonin on macrophages/microglia in postnatal rat brain. I Pineal Res 1999, 26:158-168.

93. Rai S, Haldar C: Pineal control of immune status and hematological changes in blood and bone marrow of male squirrels
(Funambulus pennanti) during their reproductively active phase. Comp Biochem Physiol C Toxicol Pharmacol 2003, I 36:31 9-328. 94. Minagar A, Shapshak P, Fujimura R, Ownby R, Heyes M, Eisdorfer C: The role of macrophage/microglia and astrocytes in the pathogenesis of three neurologic disorders: HIV-associated dementia, Alzheimer disease, and multiple sclerosis. J Neurol Sci 2002, 202: I3-23.

95. Zhang S, Li W, Gao Q, Wei T: Effect of melatonin on the generation of nitric oxide in murine macrophages. Eur J Pharmacol 2004, 50 I:25-30.

96. Barriga C, Martin MI, Ortega E, Rodriguez AB: Physiological concentrations of melatonin and corticosterone in stress and their relationship with phagocytic activity. I Neuroendocrinol 2002, | 4:69|-695.

97. Herberman RB, Ortaldo JR: Natural killer cells: their roles in defenses against disease. Science I98I, 2 | 4:24-30.

98. Trinchieri G, Perussia B: Human natural killer cells: biologic and pathologic aspects. Lab Invest 1984, 50:489-5I3.

99. Cox WI, Holbrook NJ, Grasso RJ, Specter S, Friedman H: Suppression of the natural killer cell activity of murine spleen cell cultures by dexamethasone (41489). Proc Soc Exp Biol Med 1982. I 7 I: | $46-150$

100. Angeli A, Gatti G, Sartori ML, Ponte D, Carignola R: Effect of exogenous melatonin on human natural killer (NK) cell activity. In An approach to the immunomodulatory role of the pineal gland Edited by: Gupta D, Attanasio A, Reiter RJ. Tubingen: Brain Research Promotion; 1988:145-156.

I0I. Garcia-Maurino S, Gonzalez-Haba MG, Calvo JR, Rafii-el-Idrissi M, Sanchez-Margalet V, Goberna R, Guerrero JM: Melatonin enhances IL-2, IL-6, and IFN-gamma production by human circulating CD4+ cells: a possible nuclear receptor-mediated mechanism involving $T$ helper type I lymphocytes and monocytes. J Immunol 1997, I 59:574-58I.

102. Drazen DL, Nelson RJ: Melatonin receptor subtype MT2 (mel Ib) and not MTI (mel $\mathrm{Ia}$ ) is associated with melatonininduced enhancement of cell mediated and humoral immunity. Neuroendocrinology 200।, 74:|78-184.

103. Carrillo-Vico A, Garcia-Perganeda A, Naji L, Calvo JR, Romero MP, Guerrero JM: Expression of membrane and nuclear melatonin receptor mRNA and protein in the mouse immune system. Cell Mol Life Sci 2003, 60:2272-2278.

104. Garcia-Maurino S, Pozo D, Carrillo-Vico A, Calvo JR, Guerrero JM: Melatonin activates ThI lymphocytes by increasing IL-I 2 production. Life Sci 1999, 65:2143-2150.

105. Morrey KM, McLachlan JA, Serkin CD, Bakouche O: Activation of human monocytes by the pineal hormone melatonin. J Immunol 1994, I 53:267|-2680.

106. Barjavel MJ, Mamdouh Z, Raghbate N, Bakouche O: Differential expression of the melatonin receptor in human monocytes. J Immunol 1998, 160:1191-1197.

107. Lissoni P, Rovelli F, Brivio F, Brivio O, Fumagalli L: Circadian secretions of IL-2, IL-I 2, IL-6 and IL- I 0 in relation to the light/dark rhythm of the pineal hormone melatonin in healthy humans. Nat Immun 1998, I 6: I-5.

108. Liu F, Ng TB, Fung MC: Pineal indoles stimulate the gene expression of immunomodulating cytokines. J Neural Transm 200।, I 08:397-405

109. Fulop T Jr, Wagner JR, Khalil A, Weber J, Trottier L, Payette H: Relationship between the response to influenza vaccination and the nutritional status in institutionalized elderly subjects. J Gerontol A Biol Sci Med Sci 1999, 54:M59-M64.

I 10. Khanna KV, Markham RB: A perspective on cellular immunity in the elderly. Clin Infect Dis 1999, 28:710-713.

III. Csaba G, Barath P: Morphological changes of thymus and the thyroid gland after postnatal extirpation of pineal body. Endocrinol Exp 1975, 9:59-67

112. Liu ZM, Pang SF: [1/25]-labelled iodomelatonin binding sites in the duck bursa of Fabricius: binding characteristics and diurnal variation. Neurosci Lett 1992, I46:163-166.

II3. Maestroni G], Conti A, Pierpaoli W: Role of the pineal gland in immunity. III. Melatonin antagonizes the immunosuppressive effect of acute stress via an opiatergic mechanism. Immunology 1988, 63:465-469.

I 14. Tian YM, Zhang GY, Dai YR: Melatonin rejuvenates degenerated thymus and redresses peripheral immune functions in aged mice. Immunol Lett 2003, 88:101-104. 
I 5. Sainz RM, Mayo JC, Reiter RJ, Antolin I, Esteban MM, Rodriguez C: Melatonin regulates glucocorticoid receptor: an answer to its antiapoptotic action in thymus. FASEB J I999, I 3: I547-I556.

I16. Tian YM, Li PP, liang XF, Zhang GY, Dai YR: Rejuvenation of degenerative thymus by oral melatonin administration and the antagonistic action of melatonin against hydroxyl radical-induced apoptosis of cultured thymocytes in mice. J Pineal Res 2001, 31:214-221.

I I7. Maestroni GJ: The immunoneuroendocrine role of melatonin. $J$ Pineal Res 1993, 14:1-10.

I 18. Yu Q, Miller SC, Osmond DG: Melatonin inhibits apoptosis during early $B$ cell development in mouse bone marrow. J Pineal Res 2000, 29:86-93.

I19. Nelson RJ, Drazen DL: Melatonin mediates seasonal changes in immune function. Ann N Y Acad Sci 2000, 9 I 7:404-4I5.

120. Moore CB, Siopes TD: Effects of lighting conditions and melatonin supplementation on the cellular and humoral immune responses in japanese quail coturnix coturnix japonica. Gen Comp Endocrinol 2000, I I 9:95-104.

121. Moore CB, Siopes TD: Melatonin enhances cellular and humoral immune responses in the Japanese quail (Coturnix coturnix japonica) via an opiatergic mechanism. Gen Comp Endocrinol 2003, I31:258-263.

122. Conti A, Conconi S, Hertens E, Skwarlo-Sonta K, Markowska M, Maestroni JM: Evidence for melatonin synthesis in mouse and human bone marrow cells. J Pineal Res 2000, 28: 193-202.

123. Gonzalez-Haba MG, Garcia-Maurino S, Calvo JR, Goberna R, Guerrero JM: High-affinity binding of melatonin by human circulating T lymphocytes. (CD4+). FASEB J 1995, 9: | 33 |- I 335.

124. Garcia-Perganeda A, Pozo D, Guerrero JM, Calvo JR: Signal transduction for melatonin in human lymphocytes: involvement of a pertussis toxin-sensitive G protein. J Immunol 1997, | 59:3774-378|

125. Carrillo-Vico A, Garcia-Maurino S, Calvo JR, Guerrero JM: Melatonin counteracts the inhibitory effect of PGE2 on IL-2 production in human lymphocytes via its mt membrane receptor. FASEB J 2003, I 7:755-757.

126. Castrillón P, Esquifino AI, Varas A, Zapata A, Cutrera RA, Cardinali DP: The effect of melatonin treatment on $24 \mathrm{hr}$ variations in response to mitogens and lymphocyte subpopulations in rat submaxillary lymph nodes. J Neuroendocrinol 2000, I 2:758-765.

127. Nunnari G, Nigro L, Palermo F, Leto D, Pomerantz RJ, Cacopardo B: Reduction of serum melatonin levels in HIV-I-infected individuals' parallel disease progression: correlation with serum interleukin- I 2 levels. Infection 2003, 3 I:379-382.

I28. Raghavendra V, Singh V, Shaji AV, Vohra H, Kulkarni SK, Agrewala JN: Melatonin provides signal 3 to unprimed CD4+ $T$ cells but failed to stimulate LPS primed B cells. Clin Exp Immunol 200I, I 24:4|4-422.

129. Maestroni GJM, Cardinali DP, Esquifino AI, Pandi-Perumal SR: Does melatonin play a disease-promoting role in rheumatoid arthritis? J Neuroimmunol 2004, I 58: I06-I I I.

130. Regodon S, Martin-Palomino P, Fernandez-Montesinos R, Hererra JL, Carrascosa-Salmoral MP, Piriz S, Vadillo S, Guerrero JM, Pozo D: The use of melatonin as a vaccine agent. Vaccine 2005, 23:532I-5327.

131. Kammer GM: The adenylate cyclase-cAMP-protein kinase A pathway and regulation of the immune response. Immunol Today 1988, 9:222-229.

132. Wei W, Shen YX, Dai M, Chen Q: Effects and mechanisms of melatonin on immune responses in mice of different months. Acta Pharmacol Sin 2003, 24:719-723.

133. Maestroni GJ, Conti A: Anti-stress role of the melatoninimmuno-opioid network: evidence for a physiological mechanism involving T cell-derived, immunoreactive beta-endorphin and MET-enkephalin binding to thymic. opioid receptors. Int J Neurosci 1991, 6 I:289-298.

134. Kidd P: ThI/Th2 balance: the hypothesis, its limitations, and implications for health and disease. Altern Med Rev 2003, 8:223-246.

135. Peterson JD, Herzenberg LA, Vasquez K, Waltenbaugh C: Glutathione levels in antigen-presenting cells modulate $T h I$ versus Th2 response patterns. Proc Natl Acad Sci U S A 1998, 95:307I-3076.

136. Murata Y, Shimamura T, Hamuro J: The polarization of Th I/Th2 balance is dependent on the intracellular thiol redox status of macrophages dueto the distinctive cytokine production. Int Immunol 2002, I 4:201-2I2.

137. Murata Y, Amao M, Hamuro J: Sequential conversion of the redox status of macrophages dictates the pathological progression of autoimmune diabetes. Eur J Immunol 2003, 33:1001-1011.

138. Urata Y, Honma S, Goto S, Todoroki S, lida T, Cho S, Honma K, Kondo $\mathrm{T}$ : Melatonin induces gamma-glutamylcysteine synthetase mediated byactivator protein-I in human vascular endothelial cells. Free Radic Biol Med 1999, 27:838-847.

139. Arendt J, Skene DJ: Melatonin as a chronobiotic. Sleep Med Rev 2005, 9:25-39.

140. Cardinali DP, Furio AM, Reyes MP, Brusco LI: The use of chronobiotics in the resynchronization of the sleep/wake cycle. Cancer Causes \& Control 2005 in press.

14I. Reiter RJ, Tan DX, Pappolla MA: Melatonin relieves the neural oxidative burden that contributes to dementias. Ann N Y Acad Sci 2004, I 035: 179-196.

142. Cardinali DP: The use of melatonin as a chronobiotic-cytoprotective agent in sleep disorders. In The Physiological Nature of Sleep Edited by: Parmeggiani PL, Velluti R. London: Imperial College Press; 2005 in press.

143. Claustrat B, Brun J, Chazot G: The basic physiology and pathophysiology of melatonin. Sleep Med Rev 2005, 9:| |-24.

144. Silva SO, Rodrigues MR, Carvalho SR, Catalani LH, Campa A Ximenes VF: Oxidation of melatonin and its catabolites, $\mathbf{N}$ acetyl-N-formyl-5 methoxykynuramine and $\mathbf{N}$-acetyl-5methoxykynuramine, by activated leukocytes. J Pineal Res 2004, 37:|7|- 175.

145. Silva SO, Rodrigues MR, Ximenes VF, Bueno-da-Silva AE, AmaranteMendes GP, Campa A: Neutrophils as a specific target for melatonin and kynuramines: effects on cytokine release. J Neuroimmunol 2004, I 56: | 46-I52.

146. Adams DH, Lloyd AR: Chemokines: leucocyte recruitment and activation cytokines. Lancet 1997, 349:490-495.

147. Bondy SC, Lahiri DK, Perreau VM, Sharman KZ, Campbell A, Zhou J, Sharman EH: Retardation of brain aging by chronic treatment with melatonin. Ann N Y Acad Sci 2004, I 035:197-2I 5.

148. Katila H, Cantell K, Appelberg B, Rimon R: Is there a seasonal variation in the interferon-producing capacity of healthy subjects? J Interferon Res 1993, I 3:233-234.

149. Maes M, Stevens W, Scharpe S, Bosmans E, De Meyer F, D'Hondt P, Peeters D, Thompson P, Cosyns P, De Clerck L, et al.: Seasonal variation in peripheral blood leukocyte subsets and in serum interleukin-6, and soluble interleukin 2 and -6 receptor concentrations in normal volunteers. Experientia 1994, 50:82 I-829.

Publish with Biomed Central and every scientist can read your work free of charge

"BioMed Central will be the most significant development for disseminating the results of biomedical research in our lifetime. "

Sir Paul Nurse, Cancer Research UK

Your research papers will be:

- available free of charge to the entire biomedical community

- peer reviewed and published immediately upon acceptance

- cited in PubMed and archived on PubMed Central

- yours - you keep the copyright
BioMedcentral 